\title{
CHRM1 wt Allele
}

National Cancer Institute

\section{Source}

National Cancer Institute. CHRM1 wt Allele. NCI Thesaurus. Code C51434.

Human CHRM1 wild-type allele is located within $11 \mathrm{q} 13$ and is approximately $13 \mathrm{~kb}$ in length. This allele, which encodes muscarinic acetylcholine receptor M1 protein, plays a role in the mediation of bronchoconstriction and in gastrointestinal acid secretion. 